Emma 0. Bérat/ Rebecca Hardie / Irina Dumitrescu (eds.)

\title{
Relations of Power
}

Women's Networks in the Middle Ages

\section{Bonn University Press}

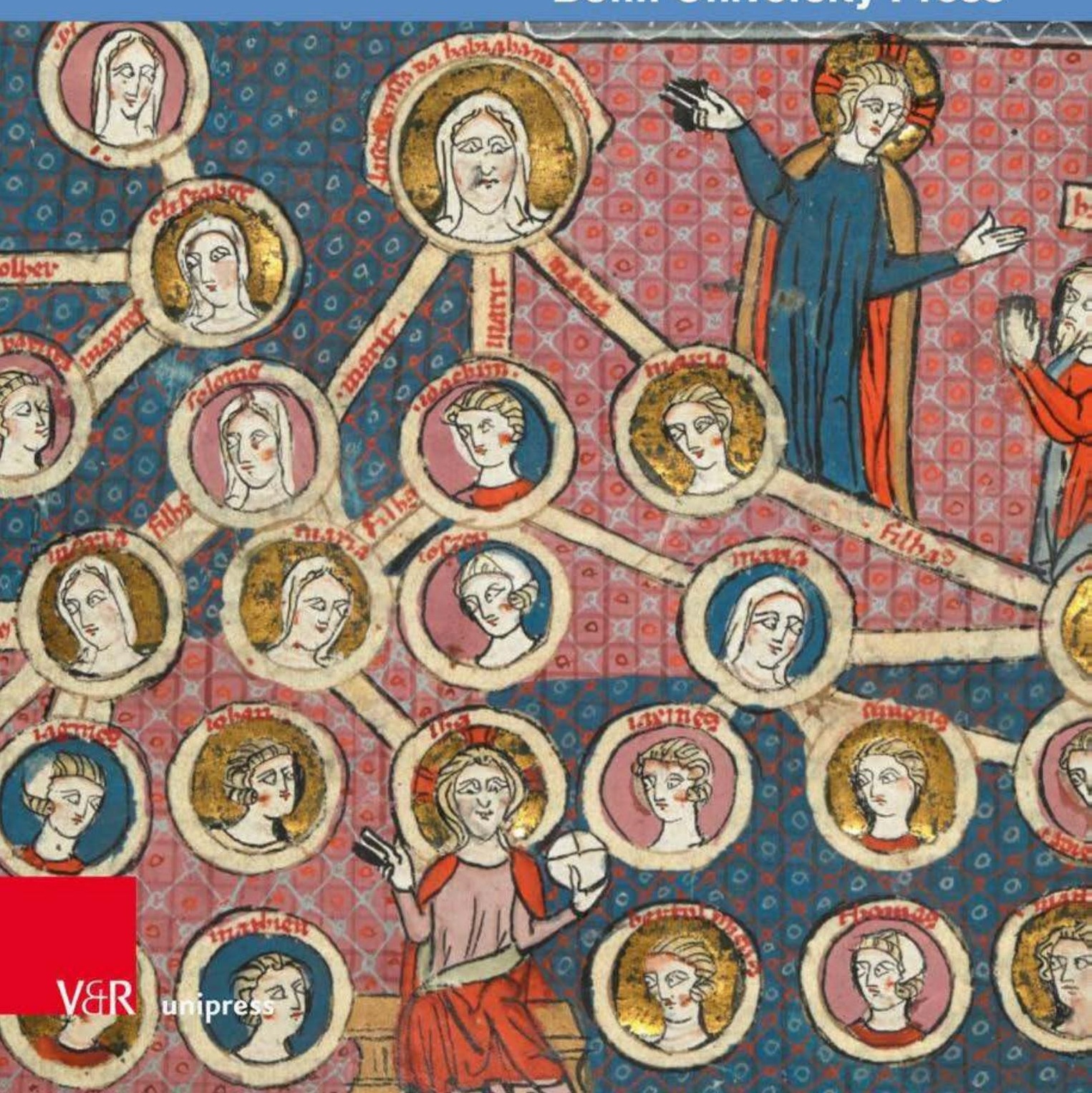




\section{V\&R unipress}

Open-Access-Publikation im Sinne der CC-Lizenz BY 4.0

(C) 2021, Vandenhoeck \& Ruprecht GmbH \& Co. KG, Göttingen

ISBN Print: 9783847112426 - ISBN E-Lib: 9783737012423 


\section{Studien zu Macht und Herrschaft}

Schriftenreihe des SFB 1167

„Macht und Herrschaft - Vormoderne Konfigurationen in transkultureller Perspektive“"

Band 5

Herausgegeben von

Matthias Becher, Jan Bemmann und Konrad Vössing 


\section{Emma O. Bérat / Rebecca Hardie / Irina Dumitrescu (eds.)}

\section{Relations of Power}

\section{Women's Networks in the Middle Ages}

With 27 figures

\section{V\&R unipress}

Bonn University Press 


\section{UNIVERSITÄT BONN

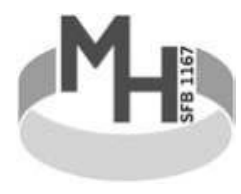

\section{DFG}

Bibliografische Information der Deutschen Nationalbibliothek

Die Deutsche Nationalbibliothek verzeichnet diese Publikation in der Deutschen

Nationalbibliografie; detaillierte bibliografische Daten sind im Internet über https://dnb.de abrufbar.

\section{Veröffentlichungen der Bonn University Press erscheinen bei V\&R unipress.}

Gedruckt mit freundlicher Unterstützung der Deutschen Forschungsgemeinschaft.

๑) 2021, Vandenhoeck \& Ruprecht GmbH \& Co. KG, Theaterstraße 13, D-37073 Göttingen Dieser Beitrag ist als Open-Access-Publikation im Sinne der Creative-Commons-Lizenz BY International 4.0 („Namensnennung“) unter dem DOI 10.14220/9783737012423 abzurufen. Um eine Kopie dieser Lizenz zu sehen, besuchen Sie https://creativecommons.org/licenses/by/4.0/. Jede Verwertung in anderen als den durch diese Lizenz zugelassenen Fällen bedarf der vorherigen schriftlichen Einwilligung des Verlages.

Umschlagabbildung: “God blessing Abraham’s posterity” (Ausschnitt), ๑ London, British Library, Royal MS 19 C I, 96r

Vandenhoeck \& Ruprecht Verlage | www.vandenhoeck-ruprecht-verlage.com 


\section{Contents}

Series Editors' Preface $\ldots \ldots \ldots \ldots \ldots \ldots \ldots \ldots$

Emma O. Bérat / Rebecca Hardie

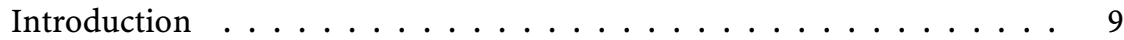

Julia Hillner / Máirín MacCarron

Female Networks and Exiled Bishops between Late Antiquity and the Early Middle Ages: The Cases of Liberius of Rome and Wilfrid of York 19

Lucy K. Pick

Networking Power and Gender at Court: An Eleventh-Century Diploma and 'Las Meninas' . . . . . . . . . . . . . . . . . . . . . 45

Jitske Jasperse

With This Ring: Forming Plantagenet Family Ties $\ldots \ldots \ldots$. . . . 67

Abigail S. Armstrong

English Royal Family Ties: Edward I and his Breton Nieces $\ldots \ldots$. . . 85

Mercedes Pérez Vidal

Female Aristocratic Networks: Books, Liturgy and Reform in Castilian

Nunneries . . . . . . . . . . . . . . . . . . . . . . 105

Stephanie Hollis

Dynastic Visions: Founder Abbesses of Wilton and Barking and their Eleventh-Century Successors . . . . . . . . . . . . . . . . . 133

Alyssa Gabbay

Mothers, Liver-Eaters and Matrilineal Descent: Hind bint 'Utba, Mu'āwiya and Nasab (Filiation) in Early Islam . . . . . . . . . . 155 


\section{Karen Dempsey}

Herstory: Exploring the Material Life of Gundrada de Warenne . . . . . . 169

List of Contributors . . . . . . . . . . . . . . . . . 197 


\title{
Karen Dempsey
}

\section{Herstory: Exploring the Material Life of Gundrada de Warenne}

\begin{abstract}
Scholarly work on castles draws on multiple sources from history, archaeology, art and architectural history to literary and religious studies. This places it in a unique position to be able to bring different threads together to tell full stories of women's lives. But a challenge exists to explore medieval women's gendered roles and their lived experience without falling prey to the trap of inserting women into traditional narratives of male power. As a first step in response to my own call for fuller archaeological accounts of women's lived experiences, this article focuses on one elite woman - Gundrada Oosterzele-Scheldewindeke, later de Warenne (d. 1085). It endeavours to capture her world through an examination of the material connections and relationships of her life. While people and places are important in this, the emphasis here is placed on our knowledge of the things that shaped Gundrada's life and death. These range from castle architecture, her much-discussed Tournai stone tombslab, an assemblage of hairpins and a devotional text, the Crowland Psalter, as well as an archaeological object with possible amuletic properties. Drawing these different strands of evidence together shows how we can foreground women, not by marking them as exceptional but to highlight that they were part of and participative within the networked material world.
\end{abstract}

\section{Introduction}

In castle studies, stories about women typically revolve around those who held stereotypical male power. This desire to highlight particular female figures and their deeds was a necessary step taken by second-wave feminist archaeologists and historians to demonstrate the presence of women as one way of subverting the patriarchal narratives within and about society in the European middle ages. While this works to highlight the diverse roles that elite women occupied, these analyses often overshadow the ways in which women exercised their own particular, gendered agency. They do little to shed light on elite women's lived experience or patterns of daily life, including their emotive and sensorial worlds. Recent work in cognate disciplines has shown that many of these aspects can be 
approached through female literary, visual and cultural networks. ${ }^{1}$ Scholarly work on castles already draws on multiple sources from history, archaeology, art and architectural history to literary and religious studies. It is in a unique position to be able to embroider women's lives - both elite and ordinary.

As a first step in response to my own call for fuller archaeological accounts of women's lived experiences, this article focuses on one elite woman - Gundrada de Warenne (d. 1085). It endeavours to capture her world through an examination of the material connections of her life. ${ }^{2}$ The local landscape of this paper is primarily Castle Acre, Norfolk but also stretches southwards into Normandy and Flanders. Our knowledge of the things that shaped Gundrada's life and death range from castle architecture, her much-discussed tomb slab, an assemblage of hairpins and a devotional text, the Crowland Psalter, to the more tenuous (sensorial) interpretations of an archaeological object, discussed here as an amulet. ${ }^{3}$ Key people include Matilda of Flanders (d. 1083) and her husband William I (d. 1088). William of Blois, Count of Boulogne (d. 1159), and his uncle Bishop Henry of Blois (d. 1171), a noted medieval patron, play smaller but still significant roles. ${ }^{4}$ Some members of the extended de Warenne family, such as Isabelle (d. 1203), as well as the successive de Warenne lords, feature briefly.

1 Diane Watt, Women, Writing and Religion in England and Beyond, 650-1100. Studies in Early Medieval History. Bloomsbury Academic, London 2019; Susan Groag BELL, Medieval Women Book Owners: Arbiters of Lay Piety and Ambassadors of Culture, in: Signs 7,4 (1982), 742-768; Jitske JASPERSE, Matilda, Leonor and Joanna: The Plantagenet sisters and the display of dynastic connections through material culture, in: Journal of Medieval History 43,4 (2017), 523-547; Elizabeth L'EsTrange, Holy motherhood: Gender, dynasty, and visual culture in the later Middle Ages, Manchester 2008; Kathleen Nolan, Queens in stone and silver: The creation of a visual imagery of queenship in Capetian France, New York 2009; Therese MARTin (ed.). Reassessing the roles of women as "makers" of medieval art and architecture, Leiden 2012. Elisabeth van Houts, Memory and Gender in Medieval Europe 900-1200, Medieval Culture and Society, Buffalo, NY 1999.

2 Karen Dempsey, Gender and Medieval Archaeology: Storming the Castle, in: Antiquity 93 (2019): 772-778.

3 John G. CoAd/Anthony D. F. Streeten, Excavations at Castle Acre Castle, Norfolk, 1972-77, in: Archaeological Journal 139 (1982), 138-301; Rebecca Rushforth, The Crowland Psalter and Gundrada de Warenne, in: The Bodleian Library Record 21 (2008), 156-68; George ZARNECKI/Janet Holt/Tristram Holland, English Romanesque Art 1066-1200. Catalogue of an Exhibition Held at Hayward Gallery, London, 5 April-8 July 1984. Arts Council of Great Britain 1984; Fiona Anderson, Uxor Mea: The First Wife of the First William of Warenne, Sussex Archaeological Collections 130 (1992), 107-819; Elisabeth van Houts, Epitaph of Gundrada of Warenne, in: Andreas Bihrer/Elizabeth Stein (eds.), Nova de Veteribus, Mitelund neulateinische Studien für Paul Gerhard Schmidt, Munchen Leipzig 2004, 366-378.

4 William I, Count of Boulogne was son of King Stephen and nephew of Henry of Blois. Henry was the grandson of William I, nephew of Henry I, bishop of Winchester and abbot of Glastonbury. See Edmund KING, Blois, Henry de (c. 1096-1171), Bishop of Winchester. Oxford Dictionary of National Biography, 2004. 
This paper takes a relational and feminist approach that enmeshes people, places and things of various scales within the same narrative. In doing so, the interwoven threads of Gundrada's personal, political, familial and spiritual relationships are captured. ${ }^{5}$ When grappling with disparate and impartial evidence to reveal the material and networked life of Gundrada, some of the narrative will be somewhat speculative, but the connections made here demonstrate the strength of engaging with a variety of sources. ${ }^{6}$

\section{Who was Gundrada de Warenne?}

Gundrada was a Flemish noblewoman from the family Oosterzele-Scheldewindeke, hereditary advocates of St Bertin at St Omer. ${ }^{7}$ In the late nineteenth century, she was of great interest to historians/genealogists, who tried to establish if she was a daughter to William I (d. 1087), also known as the Conqueror, and/or Matilda of Flanders (d. 1083). ${ }^{8}$ It became clear that this genealogy was based on misunderstandings of historical documents. ${ }^{9}$ Despite not being immediately related to this royal couple, it appears that she was deeply connected to Matilda, which is evidenced in particular by the gift of the manor of Carlton, Cambridgeshire in England from the queen to Gundrada. ${ }^{10}$ This has been understood as indicative of a close relationship - perhaps that of a lady-in-waiting, a role that can sometimes be akin to that of a surrogate daughter. ${ }^{11}$ There are also suggestions that Matilda and Gundrada were possibly related, if only distantly. ${ }^{12} \mathrm{Un}$ fortunately, little is known of Gundrada's early life. But if we accept that she was part of Matilda of Flanders' immediate circle, then perhaps through a brief examination of her life, we can know more of Gundrada.

5 Elisabeth van Houts, The Warenne View of the Past 1066-1203, in: Anglo-Norman Studies XXIV, Proceedings of the Battle Conference 200326 (2004), 103-121.

6 Ruth Tringham, Giving Voices (Without Words) to Prehistoric People: Glimpses into an Archaeologist's Imagination, in: European Journal of Archaeology 22,3 (2019), 338-353.

7 The Warenne (Hyde) Chronicle, eds. and trans. Elisabeth van Houts/Rosalind C. Love, Oxford 2013.

8 Edward A. Freeman, The Parentage of Gundrada, Wife of William of Warren, in: The English Historical Review 3,12 (1888), 680-701; Mary Anne Everett Green, Lives of the Princesses of England: from the Norman Conquest (1849-1855), vol. 1, London 1857, 72-82.

9 Van Houts/Love 2013; Anderson 1992; William Farrer/Charles Travis Clay, Early Yorkshire Charters Volume 8: The Honour of Warenne, Cambridge 1949, 40-45.

10 Van Houts 2004; Joanna Green, The Aristocracy of Norman England, Cambridge 1997. Gundrada later gifted this to Lewes Priory, discussed below.

11 Van Houts/Love 2013; Jennifer WARD, English Noblewomen in the Later Middle Ages, New York 1992.

12 VAn Houts 2004, 104. 
As a Flemish noble, Gundrada may have spent some time at the court of Baldwin V (d. 1067) and Adelda (d. 1079), Count and Countess of Flanders, who were Matilda's parents. Matilda I married c. 1051, which coincided with the approximate date of Gundrada's birth. If Gundrada was a lady-in-waiting, she may have joined Matilda's new household as young as five years old. ${ }^{13}$ While we don't know exactly where Gundrada spent her time as part of Matilda's household, we do know that as a noblewoman, the material context of her life would have been rich; she likely visited churches and cathedrals with ornate architecture, as well as experiencing life in a castle surrounded by tapestries, silks, cloth and fine bed clothes, as is documented for Matilda.

Queen Matilda was known to have placed an emphasis on learning at court and for her children. ${ }^{14}$ She founded the Abbey of Sainte-Trinité, Caen in Normandy, where she was later buried. This nunnery, also known as the Abbaye aux Dames, was thought specifically to have fulfilled the educational needs of her daughters. ${ }^{15}$ One of whom, Cecelia (d. 1126), went on to become the abbess of this Benedictine Abbey. ${ }^{16}$ How does this relate to Gundrada? Within the royal household, noblewomen often provided childcare and served as nursemaids. ${ }^{17}$ Given the frequency of international marriages, language learning must have been an important part of growing up. ${ }^{18}$ So it may be that ladies-in-waiting, who themselves had likely been educated at court, were expected, once old enough, to share their knowledge, perhaps including languages, if they were involved in childcare or companionship. ${ }^{19}$

As a woman, there were certain societal expectations placed on Gundrada. These gendered roles of medieval women were many, including care and nurture

13 WARD 1992; Barbara HARRIS, English Aristocratic Women, 1450-1550, Oxford 1992.

14 Lisa Hilton, Queens Consort: England's Medieval Queens, London 2009; VAN Houts 1992.

15 The Gesta Normannorum Ducum of William of Jumièges, Orderic Vitalis and Robert of Torigni, ed. Elisabeth van Houts, Oxford 1992.

16 Laura L. Gathagan, "Mother of Heroes, Most Beautiful of Mothers". Mathilda of Flanders and Royal Motherhood in the Eleventh Century, in: Carey Fleiner/Ellie Woodacre (eds.), Virtuous or Villainess? The Image of the Royal Mother from the Early Medieval to the Early Modern Era, New York 2016, 37-63.

17 Ward 1992; Michael Clanchy, Did Mothers Teach Their Children to Read?, in: Conrad Leyser/Lesley Smith (eds.), Motherhood, Religion, and Society in Medieval Europe, 4001400, London 2016, 147-172.

18 Ian SноRт, Patrons and Polyglots: French Literature in Twelfth-Century England, in: AngloNorman Studies 14 (1991), 229-249; ClanCy 2016; Elizabeth M. Tyler, Crossing Conquests: Polyglot Royal Women and Literary Culture in Eleventh-Century England, in: Elizabeth M. TYLER (ed.), Conceptualizing Multilingualism in Medieval England, c800-c1250 (2011), 17196.

19 Mary Lewis, Work and the Adolescent in Medieval England ad. 900-1550: The Osteological Evidence, Medieval Archaeology 60,1 (2016), 138-171; Jeremy P. GoLDBERG, Women, Work, and Life Cycle in a Medieval Economy, Oxford 1992. Both texts discuss working ages of young people from eight years old and up. 
for their households and beyond, as well as the patronage of religious institutions, which was wrapped up in their own expressions of religious devotion. ${ }^{20}$ The queen and her ladies-in-waiting likely took part in celebrations at court, whether in Flanders, Boulogne or Normandy, most of which revolved around the church calendar. ${ }^{21}$ Daily life, aside from eating, likely involved praying and reading homilies from a personalised prayer book, weaving or some form of textile work, performing hospitality and, for some women, administration of the household.

Gundrada was about seventeen years old when she married William de Warenne (d. 1086) soon after the Battle of Hastings in 1066, which ultimately meant her leaving Matilda's household. We know little about Gundrada's migration to England, but she and her brother Frederick (d. 1070?) held lands in southern England prior to the Conquest. ${ }^{22}$ Owing to the successful battle campaign, William de Warenne was richly rewarded with estates in the area of modern Sussex. Interestingly, his new territory appeared to complement that of Gundrada, who inherited further lands after her brother Frederick's death. It has been suggested that Gundrada held these particular estates throughout her life; one manor continued to be known as Frederick's, and in 1086, this was listed as belonging to the Abbey of St Bertin in Flanders. ${ }^{23}$ Was this a gift to the Abbey from Gundrada in memory of her brother? If so, it could be considered an early indication of her desire to curate the memory of her family. At the same time, it would reaffirm a connection with Flanders.

\section{A Home from Home? Castle Acre in Context}

Castle Acre (Norfolk) and Lewes (Sussex) were the main seats established by William and Gundrada in England shortly after $1066 .{ }^{24}$ Castle Acre is now understood as one of the largest earthwork castles in England. However, archaeological excavation has shown that at the time Gundrada was living here, its morphology was different as it did not yet have the surrounding large ditches and banks that are visible today (Fig. 1). Initially, the Castle Acre complex comprised

20 Martin 2012; Kim M. Phillips, A Cultural History of Women in the Middle Ages, Sydney 2016.

21 Roberta Gilchrist, Medieval Life. Archaeology and the Life Course, Woodbridge 2012 notes that the church calendar was entwined with life in the Middle Ages.

22 Van Houts/Love 2013; Lewis C. Loyd, The Origins of the Family of Warenne, in: Yorkshire Archaeological Journal 31 (1934), 97-113.

23 Van Houts/Love 2013; Loyd 1934; George E. Cokayne, The Complete Peerage, vol. 4, London 1916, 670.

24 Lewes Castle was the first castle founded by the married couple. It too was originally an earth and timber castle with a later masonry focal building. 
a circular chalk bank likely surmounted by a wooden palisade, complete with a timber gatehouse to the south. Enclosed within this was the primary focal building, a two-storeyed structure with accommodation in two ranges. ${ }^{25}$ The relative simplicity of the residential building does not imply it was insubstantial there is evidence for high-status elements, such as a wall fireplace, one of the earliest examples in England. ${ }^{26}$

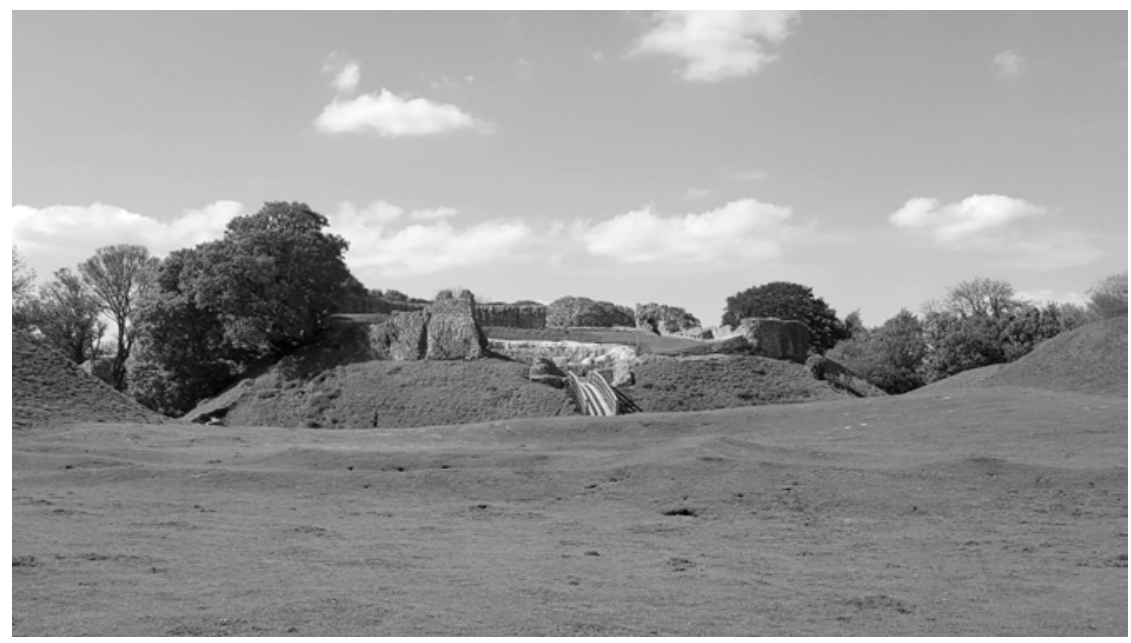

Fig. 1: Castle Acre, Norfolk from south. Showing earthworks and masonry remains. Author's own.

Direct parallels for this elite residence are not immediately obvious, as few known contemporary buildings survive; though Bletchingley, Surrey and Walmer, Kent could be contenders, as well as the twelfth-century Wolvesey Palace, Winchester. ${ }^{27}$ However, the style of Castle Acre's architecture, with its dual upper levels and wall fireplaces, can be linked back to elite residences in Normandy, including the early castle at Caen, Ivry-la-Bataille or Avranches. While Château de Caen did not become the seat of power for Matilda and William until c. $1060,{ }^{28}$

25 CoAd/Streeten 1982.

26 Margaret Wood, The English Medieval House, London 1965.

27 Michael W. Thompson, Keep or Country House? Thin-walled Norman "proto-keeps", in: Fortress 12 (1992), 13-22; Michael Thompson, Another "Proto-Keep" at Walmer, Kent, in: Medieval Archaeology 39 (1994), 174-176.

28 Edward Impey/John McNeill, The Great Hall of the Dukes of Normandy in the Castle at Caen, in: John A. Davies et al. (eds.), Castles and the Anglo-Norman World, Barnsley 2016, 75-97; Lucien Musset, Les Actes de Guillaume le Conquérant et de la Reine Mathilde pour les Abbayes Caennaises, in: Mémoires de la Société des Antiquaires de Normandie 37 (1967), 5962; Michel de BoüArd, Le Château de Caen, Caen 1979; Bénédicte Guillot, Caen (Calvados). Castle, in: Medieval Archaeology 43 (2013), 256-257. 
it is possible that Gundrada aspired to capture aspects of Matilda's domestic arrangements for herself in Castle Acre. This was not unusual; many Norman castles in England drew on pre-existing architectural styles. The masons who constructed these new buildings would also have been brought from Normandy since there was no tradition of stone building of large-scale domestic architecture in early medieval England. The family of Gundrada's husband, William, also originated in Normandy, and perhaps it was necessary or even comforting to draw upon familiar architecture to create a new home.

Castle Acre, and other high-status estates, became part of the material network of the de Warenne family belonging to successive generations, all of which began with Gundrada. For centuries, these castles were occupied by high-ranking nobles, as well as ladies-in-waiting, male attendants, saddlers, laundresses and cooks who lived, worked or visited there. Castle Acre was a place where many grand stories played out from the period directly after the Norman Conquest to the turbulent times of the mid-twelfth century and onwards; kings and queens visited, daughters made marriage alliances and land was confiscated and returned. ${ }^{29}$ The archaeological evidence from the castle captures this macroscale but also highlights the smaller stories of daily life. It shows that people made butter, carved bone instruments, consciously buried coins and tokens in building foundations as special deposits to commemorate their creation and even etched female figures into the lower courses of an interior wall. ${ }^{30}$ This was the material world of Gundrada, who was a central node within the daily running and decision making of the castle household.

\section{Creating Connections: From Caen to Cluny and Castle Acre}

Female patronage of religious houses was one aspect of the gendered role of elite medieval women that was also interlinked with their devotional activities of prayer on behalf of their family. ${ }^{31}$ Following in the footsteps of other generous sponsors, such as Matilda I and her mother Adela of France, Gundrada was interested in performing her appropriate role as benefactor. ${ }^{32}$ This is most visible in her joint patronage of the first Cluniac Priory in England at Lewes, Sussex c. 1077 with her husband William. This was constructed at the established shrine of St Pancras, from which it took its name. Gundrada donated a portion of her dower lands to the abbey, which included the manor of Carlton previously gifted

29 CoAd/Streeten 1982.

30 Ibid.

31 Martin 2012.

32 Also recognised is her potential donation of Frederick's manor to St Riquer. See VAN Houts 1995. 
to her by Matilda. ${ }^{33}$ She is listed on its foundation charter as 'Gundrede uxoris $W$. de Warenna', where an " $\mathrm{X}$ " represents her signature, at the lower left of the document (Fig. 2). ${ }^{34}$ The foundation charter of this religious house was co-signed by Matilda and William I. This signed document is a tangible demonstration of the close relationship between these four individuals: Signum Willelmi regis Anglorum. Signum M. regine Anglorum. S. Willelmi comitis filii regis. Signum Willelmi de Warenna. S. Gundrede uxoris W. de Warenna. ${ }^{35}$

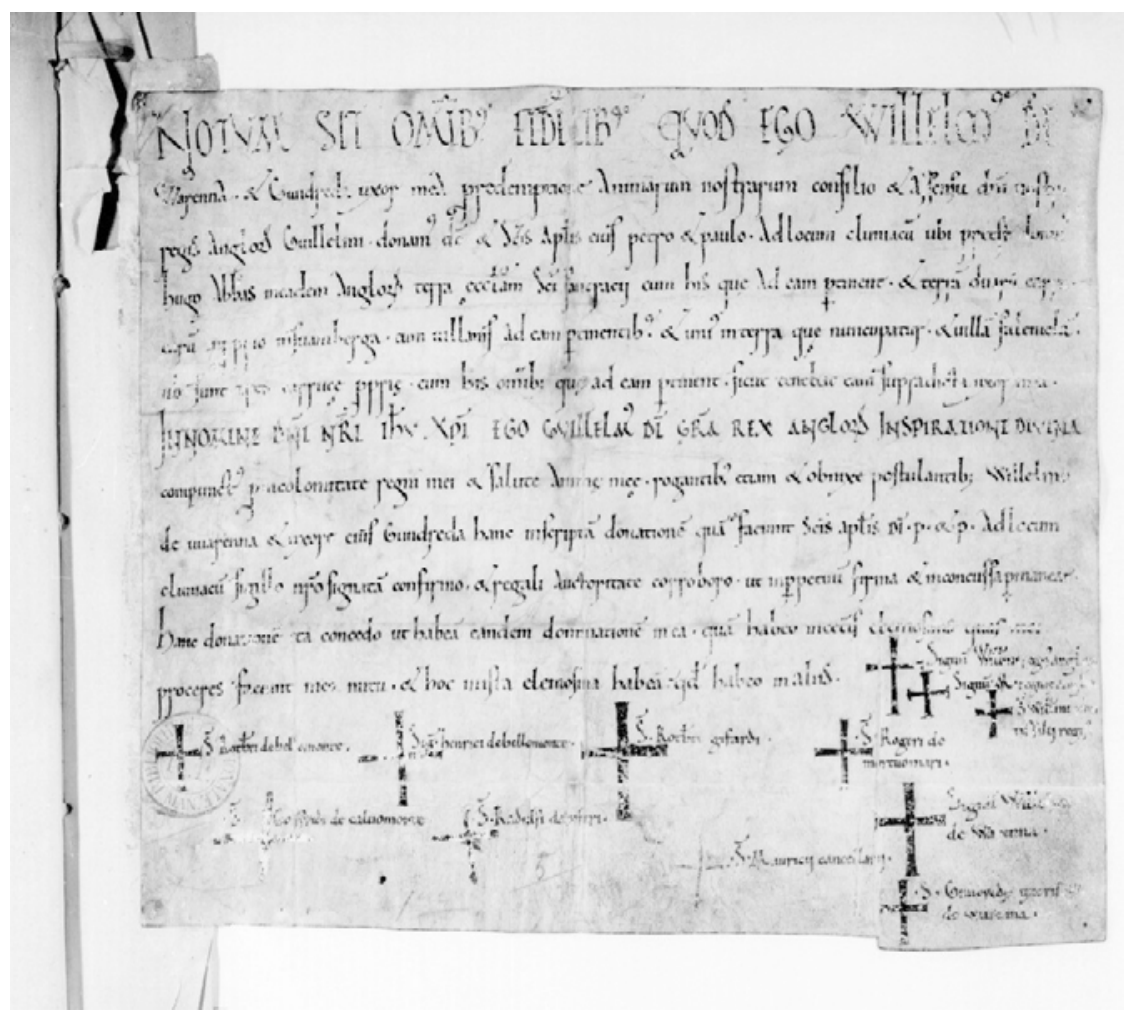

Fig. 2: Foundation Charter of Lewes Priory. Paris, Bibliothèque nationale de France, Département des manuscrits. Bourgogne 78. https://www.europeana.eu/en/item/9200519/ark_12148_btv1b1 0034022 p.

33 Farrer/Clay 1949, 43; George F. Duckett, Charters of the Abbey of Cluni: More particularly affecting its Affiliated Priory of St Pancras, at Lewes, in: Sussex Archæological Collections 34 (1886), 121-126.

34 Freeman 1888, 686; Paris, Bibliothèque nationale de France, Bourgogne 78, http:// archivesetmanuscrits.bnf.fr/ark:/12148/cc92402h/cd0e1553.

35 Ibid; Green 1857, 77, noted that Gundrada's seal was affixed. Future research will ascertain if the original charter retains any wax seal impressions. 
Close to c. 1080, a sister house of Lewes was constructed at Castle Acre. The original establishment was located within the extent of the castle, where a small community of monks were housed within a possible pre-Conquest church. ${ }^{36}$ It was not until the next generation - William de Warenne II (d. 1138) and Isabel de Vermandois (d. 1131) - that the priory's most elaborate size and scale were fully realised. This monastic complex was re-located to the east, bookending the town with the castle (Fig. 3). Its church was modelled on those of both Lewes and Cluny. It comprised Caen stone, which was common building material at this date, but the precise location of the quarry at the new Norman seat of power is significant. Gundrada was connected to these places, as was her husband William, perhaps indicating that their material choices and those of their descendants reflect the networks of kinship and political allegiances that they were embedded within and endeavouring to maintain.

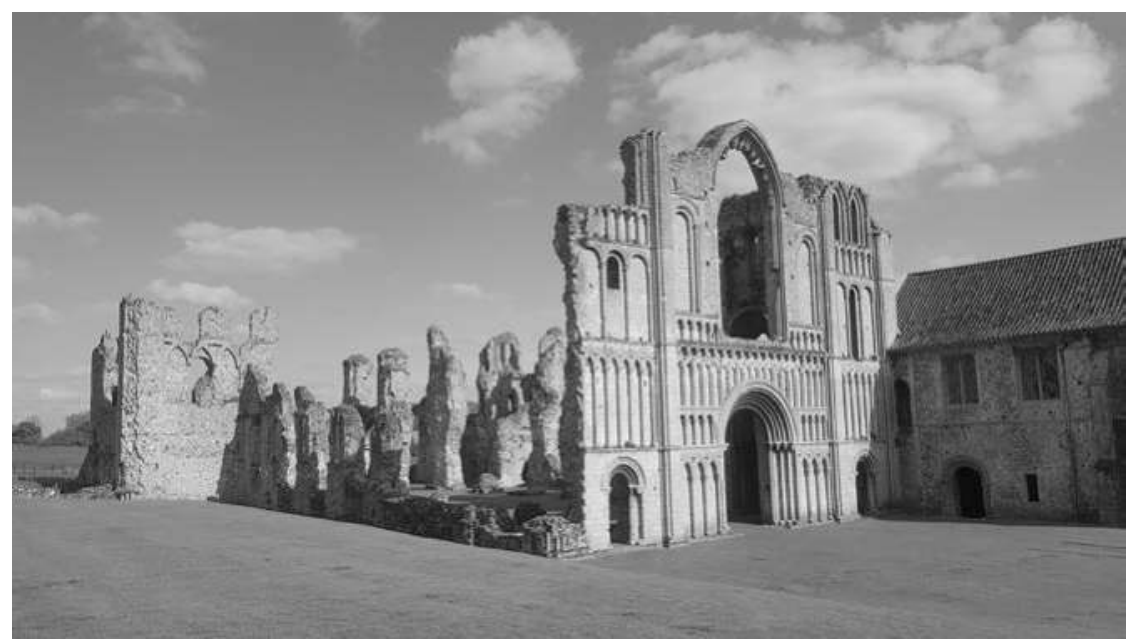

Fig. 3: Castle Acre Priory from northwest showing church and west façade. Author's own.

How this interlinked web of Cluny, Lewes and Gundrada, as well as William and Matilda, occurred deserves further attention. Gundrada's brother Gerbod accidentally killed his liege lord, Arnulf III (d. 1071), in battle in Flanders. ${ }^{37}$ He fled first to Rome, then subsequently to Cluny, where Abbot Hugh allowed Gerbod to take a monastic vow and live out his life as a monk. ${ }^{38}$ It seems that Gundrada and William travelled to Cluny to broker a deal whereby, as repayment for the reprieve of her brother, the married couple would establish a monastery firstly at

36 Edward Impey, Castle Acre Castle and Priory. English Heritage Guidebook, London 2008.

37 ANDERSON 1992.

38 Van Houts 1999. 
Lewes and later at Castle Acre. It is likely that there may have been pressure on the abbot to accommodate this request as Matilda, Queen of England, was aunt to Arnulf and also related distantly to Gerbod. ${ }^{39}$ The couple's confirmation of the foundation of St Pancras Priory, Lewes, as well as their gifts, is recorded within Cluny charters, as is a note that the abbot would carry out their request. ${ }^{40}$ The royal couple, along with Gundrada and William, became signatories on the foundation charter, an act that tied them together more strongly. The patronage of Lewes Priory as a form of penance by Gundrada on behalf of her brother should not be too surprising as medieval women often completed these tasks, acting as intercessors or "bridges". ${ }^{41}$ In this way, women were key links in the chain to facilitate penance or mediate difficult relationships, whether familial or church-related. As we will see in the next section, this process did not end with death.

\section{The Curious Case of Gundrada's Tomb Slab: Memory, Materiality and Marriages}

Orderic Vitalis, writing in the twelfth century, recorded that William de Warenne was buried in the chapterhouse at Lewes; he noted that the tomb was white with an epitaph, which he transcribed. ${ }^{42}$ The "white tomb" was likely constructed from Caen limestone, also used as part of the decorated stonework at Lewes Priory during the twelfth century. However, he does not describe or mention anything in relation to Gundrada. In fact, he mistakenly notes that she was William's widow, despite the fact that she had died three years earlier. The Cartulary of Lewes, in an entry dated to c. 1175 , noted her death: ${ }^{43}$ obiit domina Gundrada $30 \mathrm{hu}$ [iu]s loei 28 comitissa. $^{44}$

Neither of these original tombs survives today; however, a decorated grave slab of Tournai stone was discovered in Isfield Church, Sussex, c. 1775, which contained an epitaph commemorating Gundrada. ${ }^{45}$ Its ornamentation included two

39 Van Houts/Love 2013.

40 Van Houts/Love 2013, 99 note 40.

41 Jitske JASPERSE pers. comm.; Birgit SAWYer, Women as Bridge-Builders: The Role of Women in Viking-Age Scandinavia, in: Ian Wood/Niels Lund (eds.), People and Places in Northern Europe 500-1600: Essays in Honour of Peter Hayes Sawyer, Woodbridge 1991; Lindy GranT, Blanche of Castile, Queen of France, London 2016.

42 Orderic Vitalis (1075-1142), The Ecclesiastical History of England and Normandy, transl. by Thomas Forester, vol 2, London 1980, 471-474.

43 Van Houts/Love 2013.

44 The Annals of Lewes Priory, ed. Felix Liebermann, in: The English Historical Review 17,65 (1902), 83-89.

45 See Zarnecki et al. 1984 for a description; Van Houts/Love 2013, Appendix 1. 
bands of palmette-like plant motifs, springing from carved feline heads (Fig. 4). The inscription runs along the four sides of the tombstone, as well as lengthways through the middle.

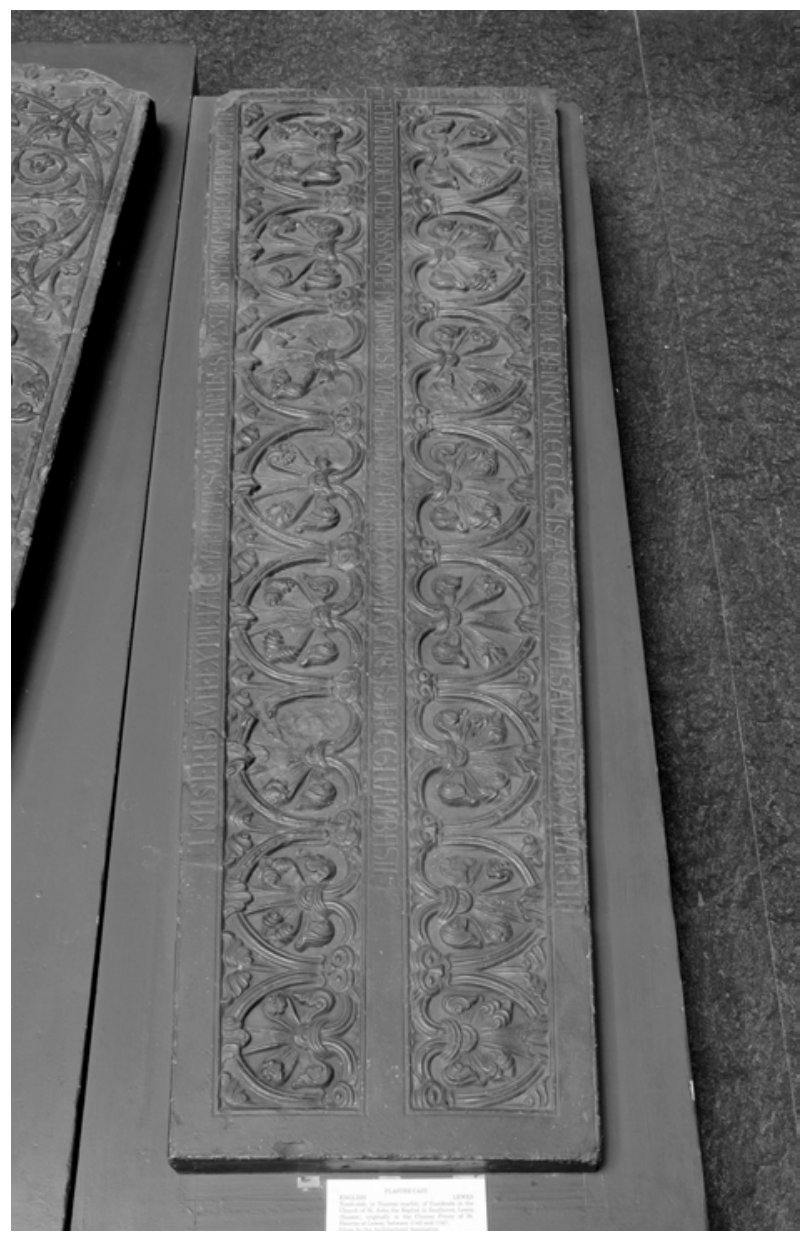

Fig. 4: Plaster cast of tombslab of Gundrada de Warenne, probably made in London, c. 1845-47. (c) Victoria and Albert Museum, London.

"Gundrada, offspring of dukes, glory of age, noble shoot, Brought to the churches of the English the balm of her character As a Martha

She was to the wretched; a Mary she was in her piety That past of Martha [in her] died; the greater part of Mary survives $\mathrm{O}$, pious Pancras, witness of truth and justice

She makes you her heir, may you in your clemency accept the mother 
The sixths days of the kalends of June, showing itself

Broke the alabaster containing her flesh". ${ }^{46}$

Later during the construction of a railway line c. 1845, which transected Lewes Priory, two lead caskets were revealed by workers. Both were inscribed with names: GVNDRADA and WILHELMUS. The caskets were surrounded by fragments of Caen stone; however, it is not clear if this represents the remains of the tomb described by Orderic. But what we can say is that at some point the original tombs were destroyed and the remains of Gundrada and William were reinterred or translated. ${ }^{47}$ The lettering on the lead caskets and the Tournai grave slab indicate a twelfth-century date, suggesting that they are contemporary. ${ }^{48}$

The origin of both the Tournai tomb slab and inscription has been subject to much debate. Art historical studies suggest that the tomb slab dated to the midtwelfth century. ${ }^{49}$ Parallels for it are drawn with other notable works, such as the blue lias capitals at Glastonbury Abbey, material from Wolvesey Palace and the sculptures from Lewes Priory. ${ }^{50}$ Elisabeth van Houts has dated the epitaph to the time of Gundrada's death, highlighting its contemporary authorship by the reference to motherhood. ${ }^{51}$ This reference served the dual purpose of acknowledging her death in childbirth whilst emphasising her role as benefactor or as a "mother" to the monastery. ${ }^{52}$ It also contained a somewhat oblique reference to the penance she paid on her brother's behalf. This suggests that Gundrada's earlier epitaph on the white Caen stone tomb was re-inscribed on a new Tournai tomb slab, which was likely created c. 1147 as part of the dedication of the new church at Lewes Priory immediately before William Warenne III (d. 1148) went on crusade. ${ }^{53}$ What happened in the time between the original inscription of the epitaph, and the later creation of the Tournai tombstone and lead caskets? ${ }^{54}$

46 Van Houts 2004.

47 Roberta Gilchrist/Cheryl Green, The chapter house, in: Cheryl Green and Roberta Gilchrist Glastonbury Abbey: Archaeological Investigations 1904-79, London 2015, 175 noted that "the remains [of some socially important individuals] were 'translated' - meaning that they were deliberately removed from their original resting place and reburied in a reverential manner".

48 Lowes 1846; William. H. BlaAuw, XXXII. Account of Two Leaden Chests, containing the Bones, and inscribed with the Names, of William de Warren and his wife Gundrada, founders of Lewes Priory in Sussex, discovered in October, 1845, within the Priory precinct, in: Archaeologia 31 (1846), 438-442.

49 ZARNECKI et al. 1984.

50 Ron BAXTER, The Medieval Worked Stone Assemblage: Romanesque Carved Stones, in: Roberta Gilchrist/Cheryl Green (eds.), Glastonbury Abbey: Archaeological Investigations 1904-79, London 2015, 347-358, here 357.

51 VAn Houts/Love 2013.

52 Ibid.

53 Ibid., ANDERson 1992. 
It is of further interest that the tombstone of Gundrada appears to be similar to that of Matilda of Flanders, whose was constructed from Tournai marble and was also rectangular in shape, with the same style of inscription, though without decoration (Fig. 5) ${ }^{55}$ Matilda died in 1083, two years before Gundrada. Matilda was buried at the Benedictine foundation of Chapelle aux Dames, Caen that she had founded. Similarly, Gundrada's final resting place was at Lewes Priory, her foundation, which was sponsored by Matilda. Tournai marble, the material of the tombstone, was associated with Flanders - both women's natal home.

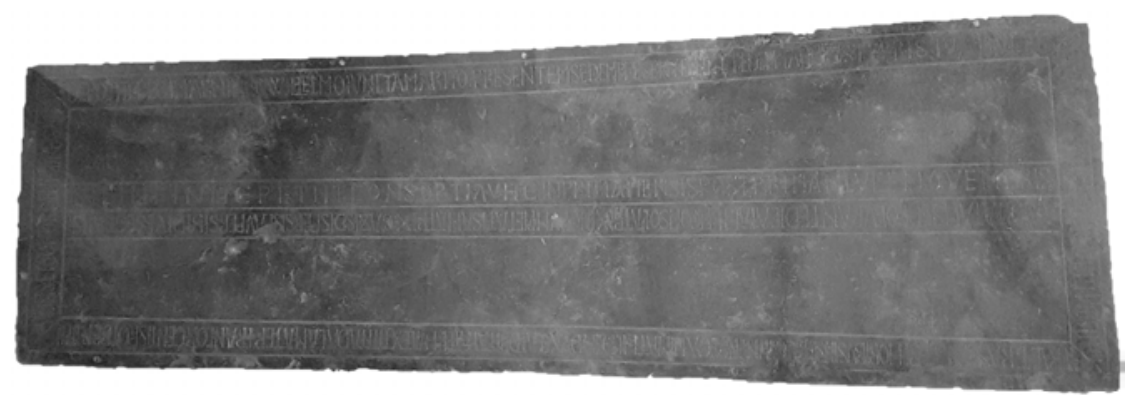

Fig. 5: Matilda of Flanders, Tombslab, Chapelle aux Dames, Caen, Normandy. Note similarities to that of Gundrada. Author's own.

Jumping forward in time from 1080s to the twelfth century, Isabelle de Warenne (d. 1203), the great-granddaughter of Gundrada, inherited the de Warenne estates c.1147. She married William of Blois (d. 1159), whose great-grandmother was Matilda of Flanders. He was also the son of King Stephen (d. 1154) and, therefore, nephew to Bishop Henry of Blois (d. 1171). Henry is considered the person to have introduced and popularised Tournai marble in England and much has already been written about his architectural patronage. ${ }^{56}$ However, the concentration on those elite male networks has obscured the female connections indicated by Gundrada's tomb. The point made here is that the tomb slab, its material, style and (re)inscription reveals of the intentions of an individual (Isabelle?) or a group such as a monastic community at Lewes who were concerned with memory making and highlights a connectedness whether socially or dynastically to Gundrada and Matilda. Gundrada's tomb slab suggests that her

54 This sort of memory-making fits within the broader cultural context e.g. Arthur's tomb at Glastonbury. See Philip Lindley, Tomb Destruction and Scholarship: Medieval Monasteries in Early Modern England, Donnington 2007; GILCHRIST/GrEEN 2015, 175.

55 Van Houts 1999.

56 ZARNECKI 1984, 148; BAXTER 2015. Much has already been written about his architectural patronage. 
influence covered several generations, affecting figures from the highest nobility including queens, kings and bishops.

\section{Fashion and Politics: Who Wears Castles in their Hair?}

Addressed so far are how Gundrada's life and death are part of wider traditions of patronage. But it is less straightforward to reveal her daily life, or indeed that of other elite women, living in castles. Biases in scholarship have a role in this, and it remains the case that the past has defaulted to a male experience. ${ }^{57}$ Difficulties in interpreting source material also play a role as material culture is largely multivalent. ${ }^{58}$ However, there are certain objects or assemblages that are typically associated with women. ${ }^{59}$ One example is a collection of 24 ornate bone pins revealed during excavation at Castle Acre..$^{60}$ Unfortunately, they do not come from a securely dated archaeological context but cover the period c. 1085-1140, a time of change within the castle that involved the construction of especially large earthworks. More broadly, these pins are thought to date to the eleventh/twelfth century but are not overly common in the archaeological record. The Castle Acre pins were interpreted by the excavator as hairpins as they are not large enough for clothing (Fig. 6). ${ }^{61}$ If so, these pins were either worn pushed through a plait or styled around the face - perhaps even sewn together with gold thread through the hair. ${ }^{62}$ This means that they were designed to be highly visible.

The Castle Acre pins are not a homogenous group. They are small - between $3 \mathrm{~mm}$ and $4 \mathrm{~mm}$ - comprising shafts with looped heads (e. g. perforated at the top of the pin), hipped heads with no loop and figurative heads. At least two of these are "castellated", meaning their heads have a jagged appearance and may reference the crenellations of a castle wall. There are other examples of these pins, most of which are found in the East Anglian or Fenland areas, including Norwich; though examples occur in Northampton and Pleshey Castles and are also known from Beverly Minster, E. Yorks and St Albans. ${ }^{63}$ The majority of the pins are

57 Dempsey 2019; Karen Dempsey et al., Beyond the Martial Façade: Gender, Heritage and Medieval Castles, in: International Journal of Heritage Studies, 26,4 (2020), 352-369.

58 Ruth Tringham, A Plea for a Richer, Fuller and More Complex Future Archaeology, in: Norwegian Archaeological Review 51 (2018), 57-63.

59 Gender correlates can be problematic; see Eleanor R. STANDLey, Spinning Yarns: The Archaeological Evidence for Hand Spinning and its Social Implications, c AD 1200-1500, in: Medieval Archaeology 60,2 (2016), 266-299.

60 CoAd/STREETEN 1982.

61 Unfortunately, despite my best effort, the only available image is a drawing from the excavation report.

62 Sue Margeson, Worked Bone, in: Coad/Streeten 1982, 241-253.

63 MARgeson 1982, 241-253. 


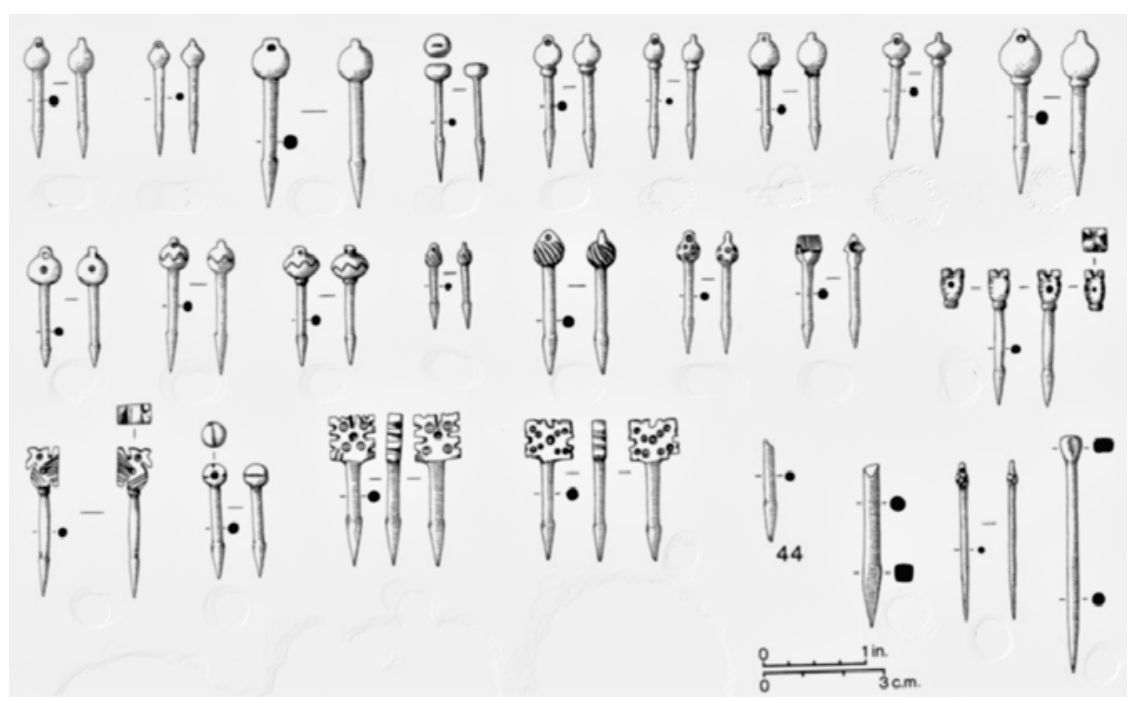

Fig. 6: Castle Acre Hairpins after Coad \& Streeten 1982, 252.

carved from animal bone, specifically pig fibula. However, there is also one copper alloy example from Castle Acre, and others are known from Winchester. ${ }^{64}$ More recently, an unusual silver example was found in Edgefield, Norfolk. ${ }^{65}$

One further example stands out: a very accomplished carved pin with a spherical head was found embedded into the mortar of Scolland's Hall, Richmond Castle, North Yorkshire (Fig. 7) ${ }^{66}$ The absence of other similar items or habitation detritus within the mortar suggests that its inclusion was no accident. The deliberate placement of particular objects in particular places is not uncommon in medieval England and fits into a wider European ritual practice of making "special deposits". ${ }^{67}$ What made this particular pin so important that a single example was included within the walls of this early castle building at Richmond? Is there something significant in its use or social meaning? The castle at Richmond was constructed by Alan Rufus whose partner was Gunnhild of Wessex (b. 1054), a noblewoman, daughter of Harold Godwinson (d. 1066) and Edith Swannesha (d. 1086). ${ }^{68}$ Is there a link here that speaks to the merging of

64 Martin BiddLe, Artefacts from Medieval Winchester: Object and Economy in Mediaeval Winchester (Winchester Studies), Oxford 1990, 554, fig. 150, nos. 1437-1438.

65 HER 44094, Treasure Annual Report 2005/6, 132, no. 559. Kindly shared with me by Dr Will WYETH, English Heritage.

66 Thanks to Will WYETH of English Heritage for drawing my attention to this.

67 Helena Hamerow, "Special deposits" in Anglo-Saxon settlements, in: Medieval Archaeology 50 (2006), 1-30; Duncan GARRow, Odd deposits and average practice. A critical history of the concept of structured deposition, Archaeological Dialogues 19 (2012), 85-115.

68 William Wyeth, pers. comm. 
differing regional identities and customs that became embodied within expressions of personal ornaments and also wider social practices?

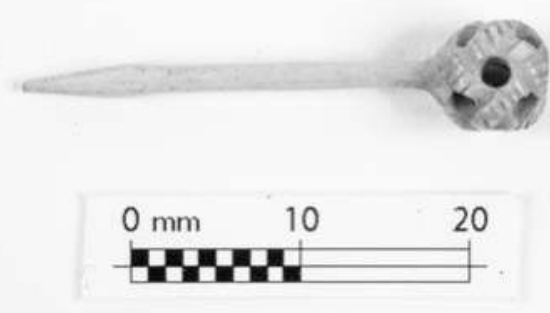

Fig. 7: Medieval bone hair (or dress?) pin c.11th century from Scolland's Hall, Richmond Castle, N. Yorks. (Accession number: 81014104) @ Historic England.

The use of these pins straddles the time from the kingdoms of Edward the Confessor (d. 1066) and Harold Godwinson (d. 1066) to that which emerged under William I (d. 1086). Bone pins start to disappear after the early thirteenth century, and it has been suggested that they could not compete in finesse with metals pins, which were essential for fastening veils. ${ }^{69}$ However, the pin from Scolland's Hall, Richmond surely indicated that this is not true. The change to metal examples might equally demonstrate that it was no longer appropriate for elite women to wear pins constructed from pig bones. It has been argued that there was a shift in pig husbandry away from pannage towards a more sty-based regimen, which perhaps affected how these animals were socially perceived. ${ }^{70}$

But who wore the castellated pins from Castle Acre? Can we imagine an elite lady wearing "castles in her hair" during the period 1080 to 1147? It is possible that the hairpins belonged to Gundrada de Warenne, her ladies-in-waiting or descendants. ${ }^{71}$ Gundrada appears to have wanted to embed herself into the local landscape of her new home as is evidenced by the creation of new sites on preexisting centres, both at Castle Acre Castle and St Pancras Priory, Lewes. This

69 David Hinton, Gold and Gilt, Pots and Pins. Possessions and People in Medieval Britain, Oxford 2006.

70 Julie Hamilton/Richard Thомas, Pannage, Pulses and Pigs: Isotopic and Zooarchaeological Evidence for Changing Pig Management Practices in Later Medieval England, in: Medieval Archaeology 56,1 (2012), 234-259. Pannage is where pigs were loosely managed and seasonally driven into woodland (HAmilton/ Thomas 2012, 235).

71 Roberta Gilchrist, The materiality of Medieval Heirlooms: From Biographical to Sacred Objects. In: Hans Peter Hahn/Hadas Weiss (eds.), Mobility, Meaning and Transformations of Things: Shifting Contexts of Material Culture through Time and Space, Oxford 2013, 170182. 
indicates a desire for dominance and power but also to communicate stability to the wider populace in a time of change or political upheaval. Her use of potentially regionally specific pins may have operated in the same way. The pins could be considered as "intermediaries": local objects framing the face of the new ruling elites, who lived in a building constructed on a pre-existing power centre. If so, this may have communicated a degree of security not only in political and religious practices but also in farming and craftwork. The pins may speak to ongoing connections between elite families both pre-and post-Conquest; they might even suggest a network of shared material culture of women that sought to bridge the divisions that must have been present in eleventh-century society.

\section{7. 'Binding' Books: The Crowland Psalter}

There has been much recent work on women's book use in material, affective, devotional and literate terms. ${ }^{72}$ But the use of books is not something that has not been discussed in relation to castles within medieval archaeology. This is somewhat surprising as a castle household contained clerks to write letters and compile household accounts; the absence of discussions on this topic is perhaps a missing link in a larger web of differing aspects of literary traditions. There is much more to be added to this interlinked network of book ownership and women's lived experiences from an archaeological perspective. It is fortunate for this article that Rebecca Rushforth has argued that Gundrada, for a time, possessed an illuminated manuscript, commonly known as the Crowland Psalter that appears to have been created in East Anglia. ${ }^{73}$

The definite provenance of the manuscript is unknown, but it likely originated in Crowland Abbey as the psalter specifically venerates saints of this fenland area. The psalter is written in Latin on parchment and decorated with a full-page miniature, a historiated initial and coloured capitals (Fig. 8). ${ }^{74}$ It dates to the eleventh century, perhaps before $1060 .{ }^{75}$ A number of additions were made after this date that are of interest to the story of Gundrada and her political and religious landscape. These included obits relating to St Pancras Priory Lewes and Cluny, as well as the insertion of dedications to the saints Faith, Katherine and Giles. This grouping does not occur together in England prior to 1050, and when it does, it is only in texts associated with Bishop Giso (d. 1088) and Leofric (d.

72 See WATt 2019 for overview.

73 Rushforth 2008. Psalter, eleventh century, 27 x $17 \mathrm{~cm}$. Oxford, Bodleian Library, MS Douce 296, 133 fols. Thanks to Professor Jocelyn WogAN-Browne for sharing this information with me.

74 Bodleian Library Summary Catalogue no. 21870.

75 RushForth 2008. 
1072), who had Flemish connections. ${ }^{76}$ Finally, a course of the Hours of the Holy Trinity was added..$^{77}$ These prayers were designed for everyday use, but the example in the Crowland Psalter has been written using feminine forms of Latin. Together, these indicate the possibility that a high-status lady who was living in the Fens with Flemish connections may have owned this book.

If, as Rushforth so convincingly argues, Gundrada owned the Crowland Psalter for a time, what does this tell us about her? This book might have been a material guide that facilitated private devotional practice. ${ }^{78}$ We must consider that she was literate with a basic knowledge of Latin. ${ }^{79}$ She was at least familiar with text owing to her "X" (if she made it) on the foundation charter of Lewes. What is of special interest here is exploring Gundrada's relationship to this object. How did she come to own it? How did the book feel to her? It was at least fifty years old when she received it and would have been touched by the hands of others. Interestingly, the manuscript does not appear to have indications of wear; the digital version is still bright and full of colour with much gold leaf throughout. The addition of the Hours of the Holy Trinity indicates it was intended for daily use, but this seems to have left little impact on the book. Perhaps the book was well cared for? Binding strips were found at Castle Acre, indicating it was possible that the book (or other manuscripts) could have been repaired or decorated there. The binding strips are similar in style to others found at Castle Rising, Norfolk and Bramber in Sussex, ${ }^{80}$ suggesting that objects related to literacy were not uncommon at castles.

To address Gundrada's acquisition of the manuscript, we must include Hereward the Wake (d. 1072) in the story. He was a nobleman and tenant of Crowland Abbey in the eleventh century before the arrival of the Normans. Hereward led or was part of a resistance movement against the Normans during which time he reportedly killed Gundrada's brother Frederick. ${ }^{81}$ It seems that Hereward knew Frederick having met him in St Omer around 1067, where the Oosterzele-Scheldewindeke family were hereditary advowsans. ${ }^{82}$ Perhaps he gifted this illuminated manuscript to Gundrada as a gesture of sorrow or as part

76 Ibid.

77 Ibid. 2008. This personalisation was completed by other noblewomen, notably Queen Margaret of Scotland (d. 1091), who was a major monastic patron and a contemporary of Gundrada. See Joanna Huntington, St Margaret of Scotland: Conspicuous Consumption, Genealogical Inheritance, and Post-Conquest Authority, in: Journal of Scottish Historical Studies 33,2 (2013), 149-164.

78 Jitske JASPERSE, pers. comm.

79 Clanchy 2016, 147-172.

80 CoAd/STREETEN 1982.

81 Elisabeth van Houts, Hereward and Flanders, in: Anglo-Saxon England 28 (1999), 201-223; van Houts/ Love 2013. As noted earlier, on his death, Gundrada's landholding grew.

82 See van Houts 1999 for further connections with Flanders. 


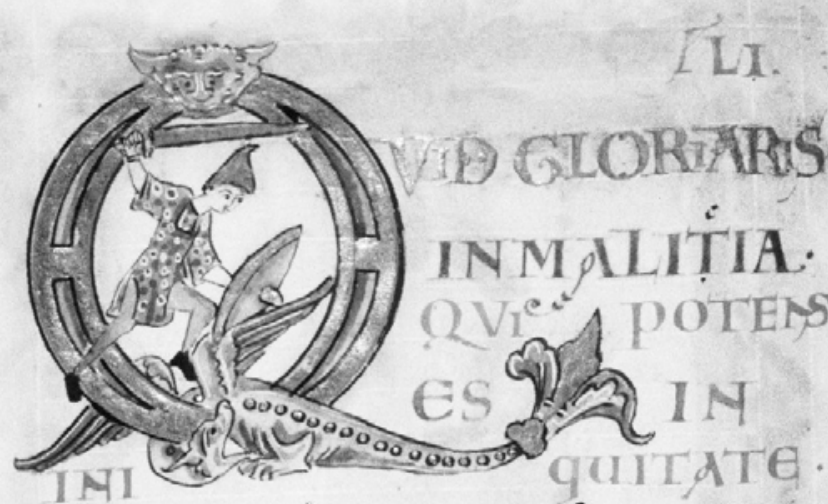

Toxadre inuultiçam cogrcaur lingrazua. ficut nouacula acura fecth dolum Oilexift maliçam iup benignicarem .

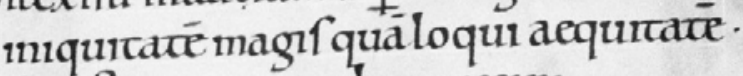

Dilexifts omma uerba precipi cazomiflingua dolôa

Properea dídettruex ue infinem . euellex re sermigrabre te decabernaculo Kradicem tuam dectra uiueraum idebune iuft sameburr. ofuper eam rideburt $\alpha$ dicenc - ecce bomo qur nonpofure deum adrutorem fuum

Sod fperture inmulaaidine diuraarum fuarū ¿ ¿preualuıe inuanicate fua Ggoaucen ficue olvua frubtifera indomo dea.fpenxu1 inmifericordia der indectnum \&infaeculum facculı

Confrabor abi infelm quia feaft sexpetabo nomen raum quoniam bonum:inconfpectu fantorum ruorū .

Fig. 8: The Crowland Psalter. Bodleian Library MS. Douce 296, fol. 040v. Photo: @ Bodleian Libraries, University of Oxford, https://digital.bodleian.ox.ac.uk/inquire/p/c28192fe-74a6-4df88628-0f963b877e20. 
of a plea of forgiveness over Frederick's death. Equally, it could have been a type of compensation. ${ }^{83}$ Both these examples show how medieval elite women could act as intercessors within disputes. It is also possible that the book was acquired during looting carried out in retribution for her brother's death and the uprising more generally. However, owing to the excellent condition of the book, this seems unlikely.

The local provenance of the book coupled with dedications to local saints would have acted as a way to create a tie between Gundrada, her new lands and the people who lived there. It would also have linked her to the former owner of the book as well as the older literary traditions of East Anglia that created it. This could be considered as a way through which she communicated her respect of the past traditions of the wider pre-Norman community, with which, no doubt, she was already quite familiar. Moving beyond the local, Gundrada's book ownership, and her devotional observances, embedded her within a much broader European network of women who displayed power and piety through similar texts. $^{84}$

\section{Senses of the Past: Protective Charms and Anxieties of Childbirth}

In patronage and wider religious practice as well as personal adornment, it is clear that Gundrada was part of a wider European cultural network. But this is also evident in her more intimate life. Gundrada already had three children before she died giving birth at Castle Acre in May $1085 .{ }^{85}$ In dying as Gundrada did, she was one of generations of women in this same position. How did they cope with or alleviate their concerns? Is it possible to try to understand Gundrada's experience as a worried (and expectant) mother through the material culture excavated at Castle Acre?

83 Compensation in this manner is not unusual. Joanna Plantagenet's son gives silver (or gold) to an abbey to compensate for the inflictions he brought upon the abbey. William I apparently founded Battle Abbey, Sussex to atone for his mis-deeds in war.

84 BeLL 1982; L'Estrange 2008. Very contemporary with Gundrada, was Judith of Flanders (c. 1032-1094), who possessed a gospel book from England. She was aunt to Matilda but also connected to England through her marriage to Tostig (d. 1066) of Northumbria, son of Harold II. See Mary Dockray-Miller, The Books and the Life of Judith of Flanders, Farnham 2015.

85 Martin Lowes, Lately Found at Lewes. Report on the Antiquities, in: Journal of the British Archaeological Association 1 (1846), 353-357. In this report, Lowes uses the phrase vi partus cruciata meaning in the pangs of childbirth, but this was not used in her obit, likely written in 1147. It was reported that an infant's remains were found with those of Gundrada; it is not currently possible to test the veracity of this statement. 
By the time Gundrada married at age seventeen, we assume that, as a noble person, she had been at a noble court for a number of years. She may have been prepared for marriage, taught about childbirth and care as well as witnessing the running a household by her mother, a mother figure or peer group. Are there certain material objects that could inform us of this knowledge exchange? The 'Sachsenspiegel', a Saxon law book written in German c. 1220, may shed some light on this (Fig. 9).

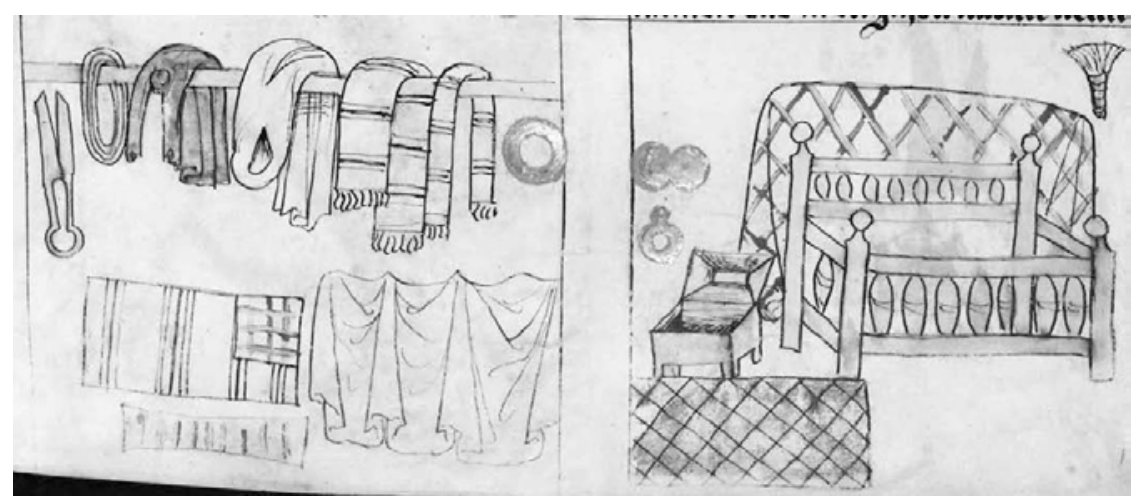

Fig. 9: The Sachsenspiegel and the Saxon (Cod. Guelf. 3.1 Aug. $2^{\circ}$; Heinemann no. 1642), http:// diglib.hab.de/mss/3-1-aug-2f/start.htm.

"Woman's property" consists of all sheep, geese, chests, all yam, bedding, coverlets, pillows, linen-clothes, table-clothes, hand-towels, bath-towels, washbasin, brass candle sticks, linen and all female dresses, rings, bangles, head adornments, psalm books and all books used in worship which women are apt to read, thereto armchairs, chests, rugs, bed-hangings, tapestries, and all fillets [...] Many small items also belong to it such as brushes, scissors, and mirrors, but I have not listed them. ${ }^{86}$

While this is from a somewhat different cultural context, in terms of historic analogy, it is still a valuable source. It contained details of certain items of women's property that were often passed from mother to daughter. ${ }^{87}$ Two iron scissors (or shears) - featured examples - were found at Castle Acre and similar items are known from the nearby Castle Rising and further away at many other sites. ${ }^{88}$ Scissors were thought to be representative of a woman's role within her household. ${ }^{89}$ In medieval England, images of shears were depicted on grave

86 Der Sachsenspiegel und das sächsische Lehnrecht, Herzog August Bibl. Wolfenbüttel, Cod. Guelf. 3.1 Aug. $2^{\circ}$ f63 17r. Available at http://diglib.hab.de/mss/3-1-aug-2f/start.htm?image= 00063.

87 BeLl 1982.

88 CoAd/STREeten 1982.

89 Aleks McClain, Cross Slab Monuments in the late Middle Ages: Patronage, Production, and Locality in Northern England, in: Sally Badham/Sophie Oosterwijk (eds.), Monumental 
markers for women. There is one example of a twelfth-century Sheela-na-gig from Egremont, Cumbria with a medieval shears. ${ }^{90}$ These were highly versatile objects, used for many things from textile work to gardening to obstetrics. ${ }^{91}$ They are intimately associated with women if we choose to read their materiality in that way.

Doubtlessly women shared objects like the psalm book, rings and bangles mentioned in the 'Sachsenspiegel', passing them from mother to daughter or among peer networks. ${ }^{92}$ These likely performed a variety of functions, including personal entertainment and ornament, but also some, especially heirlooms, may have had an apotropaic function. ${ }^{93}$ More obvious protective objects or amulets are less common in the archaeological record, but they were not unusual. ${ }^{94}$ During excavations at Castle Acre, a small pebble was revealed that was interpreted by the excavator as a possible rubbing stone. ${ }^{95}$ It was smooth, tapered and could easily fit into a person's hand. The stone type was silica, which comprised quartz, chalcedony and opals. Medieval lapidaries - books of stones explain that these opaque stones were considered powerful things. Marbode, the writer the most popular lapidary in the late eleventh century, considered chalcedony to bring victory and offer protection. ${ }^{96}$ The properties of these stones suggest that the pebble had a special meaning or magical properties for the

Industry: The Production of Tomb Monuments in England and Wales in the Long Fourteenth Century, Spalding 2010, 37-65; Roberta GILCHrist, Sacred Heritage: Monastic Archaeology, Identities, Beliefs, Cambridge 2019.

90 McClain 2010, 46; Richard BAILEY, Apotropaic Figures in Milan and North-West England, in: Folklore 94.1 (1983), 113-117. A Sheela-na-gig is a figurative stone carving of a naked female figure with an exaggerated vulva found on many medieval buildings including cathedrals, churches and castles.

91 Gilchrist 2012; Karen Dempsey, Tending the "Contested" Castle Garden: Sowing Seeds of Feminist Thought, in: Cambridge Archaeological Journal, 2020.

92 Gilchrist 2013. Although later in time to Gundrada, it seems that Alice Chaucer (d. 1475) had special birthing textiles and tapestries on display in her chamber that were on loan from the Duchess of Gloucester. See: Rachel M. Delman, Gendered Viewing, Childbirth and Female Authority in the Residence of Alice Chaucer, Duchess of Suffolk, at Ewelme, Oxfordshire, in: Journal of Medieval History 45,2 (2019), 181-203.

93 Gilchrist 2013.

94 Gilchrist 2012; Roberta Gilchrist/Barney Slohne, Requiem: The Medieval Monastic Cemetery in Britain, London 2005.

95 CoAd/STREeTEN 1982, 264 and 192. Its exact deposition location is difficult to pinpoint as the Small Finds are not mapped within the report. The stone was either originally deposited in the area of the south arch of the original upperward gatehouse or part of a soil dump in that location during the later 1140 s alterations.

96 Comm Jitske JASPERSE: De lapidibus (On Stones, ca. 1090) written by Marbode of Rennes (1035-1123), De Lapidibus, considered as a Medical Treatise with Text, Commentary and C.W. KIng's Translation Together with Text and Translation of Marbode's Minor Works on Stones, ed. and transl. by John M. RIDDLE, Wiesbaden 1977, including a list of all the Latin and vernacular manuscripts he knew of in 1977 (pp. 131-138). 
person who held it. Could "victory" mean using this stone as an amulet to triumph over a difficult event, such as childbirth? There certainly were anxieties about birth as seen through the widespread cult of St Margaret, patron saint of childbirth and expectant mothers. An exceptionally rare material example of this devotional practice comes in the form of a birthing amulet found in France that had been in use up to the nineteenth century. ${ }^{97}$

While we cannot be certain, it remains possible that the chalcedony stone, found in an archaeological context, once belonged to Gundrada or her broad contemporaries, one of whom may have deposited the stone intentionally at Castle Acre. ${ }^{98}$ Special deposits of this sort are not uncommon in the medieval world..$^{9}$ Of course, the stone could have been present in any number of hands, used as an amulet or even a toy, with its meaning different to each. The chalcedony pebble may not have been widely circulated but can be understood as one part of a network of care within women's peer groups.

\section{Material Lives}

This paper has concentrated on Gundrada Oosterzele-Scheldewindeke, later de Warenne, to tell her story from a material perspective. Her life was entangled with the biographies of many things, including buildings such as Castle Acre castle and St Pancras' Priory, Lewes, where some of the things that made her world were kept and curated, from hairpins, books and scissors to possible amulets. She was part of a community involved in sponsorship, memory making and keeping, as well as religious devotion. What is very clear is that elite women and men were aware of the materiality of things. This is most visible in the way that they understood particular materials, such as Caen or Tournai stone in monumental construction, to be particularly potent. These materials, among many others, were used (or not) to make visible the ties of the interconnected web of the ruling elite.

The de Warennes appealed to both familial and cultural connections particularly in relation to the curation of dynastic stories. This is visible in Gundrada's epitaph, where she is styled as "offspring of dukes, glory of age, noble shoot". Its deliberately ambiguous phrasing connects her to the past, present and future. This concern with temporal connections is especially apparent in how elite women and men considered how they and their families were perceived by both

97 Louis CARolus-BARré, Un nouveau parchemin amulette et la légende de sainte Marguerite patronne des femmes en couches, In: Comptes rendus de l'Académie des Inscriptions et Belles Lettres (1979), 256-275.

98 Gilchrist 2013.

99 HAMEROW 2006. 
their contemporaries and by future audiences, through the materials they used but ultimately left behind. In a reductive fashion, this might be understood as the material statement of their power, wealth and prestige. Certainly, this was part of it, but taking their likely choice of Caen stone for their tombs or Gundrada's ownership of the Crowland Psalter suggests that more than being concerned solely with material prestige, they wanted to be culturally connected to people and places in both their immediate and wider world.

To capture these links, I have endeavoured to move beyond the tension that exists between the need to faithfully represent the fragmentary evidence of the medieval archaeological record and a desire to tell a material story of women's lives. While some of this narrative is necessarily speculative, it is a starting point to engage with material culture, to bring people, especially women, into the story of the castle. It shows how we can foreground women, not by marking them as exceptional but by highlighting that they were part of and participative within the networked material world. Gundrada may not have been the daughter of Matilda of Flanders and William the Conqueror, but she was a central node in the wider material network of Norman nobility during the central Middle Ages.

\section{Acknowledgements}

This content of this article draws on the research completed during my Marie Skłodowska-Curie Fellowship 'HeRSTORY' with Prof. Roberta Gilchrist at the Dept. of Archaeology, University of Reading (2017-2019). Like the project acronym, this article is a herstory, a woman's life explored in her own right, which serves to highlight the importance of medieval women's peer-networks. I cannot disentangle my appreciation of Gundrada's network from the many medievalenthusing feminist colleagues whom I met during my HeRSTORY project, including at the workshop in Bonn.

\section{Bibliography}

\section{Sources}

Paris, Bibliothèque nationale de France, Bourgogne 78, http://archivesetmanuscrits.bnf.fr/ ark:/12148/cc92402h/cd0e1553.

The Annals of Lewes Priory, ed. Felix Liebermann, in: The English Historical Review 17,65 (1902), 83-89.

The Gesta Normannorum Ducum of William of Jumièges, Orderic Vitalis and Robert of Torigni, ed. Elisabeth van Houts, Oxford 1992. 
Historic Environment Record, England. HER 44094, Treasure Annual Report 2005/6, 132, no. 559.

Orderic Vitalis, The Ecclesiastical History of England and Normandy. Trans. by Thoms Forester, vol. 2, London, 1980, 471-474.

The Warenne (Hyde) Chronicle, eds. and trans. Elisabeth van Houts/Rosalind C. Love, Oxford 2013.

\section{Secondary literature}

Fiona Anderson, Uxor Mea: The First Wife of the First William of Warenne, in: Sussex Archaeological Collections 130 (1992), 107-819.

Susan Groag BeLL, Medieval Women Book Owners: Arbiters of Lay Piety and Ambassadors of Culture, in: Signs 7,4 (1982), 742-768.

Martin BiddLE, Artefacts from Medieval Winchester: Object and Economy in Mediaeval Winchester (Winchester Studies), Winchester 1990.

William H. BlaAuw, XXXII. Account of Two Leaden Chests, containing the Bones, and inscribed with the Names, of William de Warren and his wife Gundrada, founders of Lewes Priory in Sussex, discovered in October, 1845, within the Priory precinct, in: Archaeologia 31 (1846), 438-442.

Michel de BoüARD, Le château de Caen. Centre de recherches archéologiques médiévales, Caen 1979.

Michael Clanchy, Did Mothers Teach Their Children to Read?, in: Conrad Leyser/Lesley Sмiтн (eds.), Motherhood, Religion, and Society in Medieval Europe, 400-1400, London 2016, 147-172.

John G. CoAd/Anthony D. F. Streeten, Excavations at Castle Acre Castle, Norfolk, 197277, in: Archaeological Journal 139 (1982), 138-301.

George E. Cokayne, The Complete Peerage IV, London, 1916.

Rachel M. Delman, Gendered Viewing, Childbirth and Female Authority in the Residence of Alice Chaucer, Duchess of Suffolk, at Ewelme, Oxfordshire, in: Journal of Medieval History 45,2 (2019), 181-203.

Karen Dempsey, Gender and Medieval Archaeology: Storming the Castle, in: Antiquity 93,369 (2019), 772-778.

Karen Dempsey, Tending the "Contested" Castle Garden: Sowing Seeds of Feminist Thought, in: Cambridge Archaeological Journal, 2020.

Karen Dempsey et al., Beyond the Martial Façade: Gender, Heritage and Medieval Castles, in: International Journal of Heritage Studies, 26,4 (2020), 352-369.

George F. Duckett, Charters of the Abbey of Cluni: More Particularly Affecting its Affiliated Priory of St Pancras, at Lewes, in: Sussex Archaeological Collections 34 (1886), 121-126.

William FARrer/Charles Travis Clay, Early Yorkshire Charters, vol. 8: The Honour of Warenne, Cambridge 1949.

Edward A. Freeman, The Parentage of Gundrada, Wife of William of Warren, in: The English Historical Review 3,12 (1888), 680-701. 
Duncan Garrow, 'Odd deposits' and average practice. A critical history of the concept of structured deposition, in: Archaeological Dialogues 19 (2012), 85-115.

Laura L. Gathagan, "Mother of Heroes, Most Beautiful of Mothers". Mathilda of Flanders and Royal Motherhood in the Eleventh Century, in: Carey Fleiner/Ellie WOODACRE (eds), Virtuous or Villainess? The Image of the Royal Mother from the Early Medieval to the Early Modern Era (Queenship and Power), New York 2016, 37-63.

Roberta Gilchrist, Medieval Life. Archaeology and the Life Course, Woodbridge 2012.

Roberta Gilchrist, The Materiality of Medieval Heirlooms: From Biographical to Sacred Objects, in: Hans Peter Hahn/Hadas Weiss (eds.), Mobility, Meaning and Transformations of Things: Shifting Contexts of Material Culture through Time and Space, Oxford 2013, 170-182.

Roberta Gilchrist, Sacred Heritage: Monastic Archaeology, Identities, Beliefs, Cambridge 2019.

Roberta Gilchrist/Cheryl Green, Glastonbury Abbey: Archaeological Investigations 1904-79, London 2015.

Jeremey P. GoldBerg, Women, Work, and Life Cycle in a Medieval Economy, Oxford 1992. Lindy Grant, Blanche of Castile, Queen of France, London 2016.

Mary Anne Everett Green, Lives of the Princesses of England: from the Norman Conquest (1849-1855), vol. 1, London 1857.

Joanna Green, The Aristocracy of Norman England, Cambridge 1997.

Bénédicte Guillot, Caen (Calvados), Castle, in: Medieval Archaeology 43 (2013), 256-257.

Helena Hamerow, "Special deposits" in Anglo-Saxon settlements, in: Medieval Archaeology 50 (2006), 1-30.

Julie Hamilton/Richard Thomas, Pannage, Pulses and Pigs: Isotopic and Zooarchaeological Evidence for Changing Pig Management Practices in Later Medieval England, in: Medieval Archaeology 56,1 (2012), 234-259.

Barbara HARRIS, English Aristocratic Women, 1450-1550. Marriage and Family, Property and Careers, Oxford 1992.

Lisa Hilton, Queens Consort: England's Medieval Queens, London 2009.

David Hinton, Gold and Gilt, Pots and Pins. Possessions and People in Medieval Britain, Oxford, 2006.

Joanna Huntington, St Margaret of Scotland: Conspicuous Consumption, Genealogical Inheritance, and Post-Conquest Authority, in: Journal of Scottish Historical Studies 33,2 (2013), 149-164.

Edward Impey, Castle Acre Castle and Priory. English Heritage Guidebook, London 2008.

Edward Impey/John McNeill, The Great Hall of the Dukes of Normandy in the Castle at Caen, in: John A. Davies et al. (eds.), Castles and the Anglo-Norman World, Barnsley 2016, 75-97.

Jitske JASPerse, Matilda, Leonor and Joanna: The Plantagenet Sisters and the Display of Dynastic Connections through Material Culture, in: Journal of Medieval History 43,4 (2017), 523-47.

Edmund KING, Blois, Henry de (c. 1096-1171), Bishop of Winchester, in: Oxford Dictionary of National Biography, 2004, https://doi-org.libgate.library.nuigalway.ie/10.109 3/ref:odnb/12968 (19.12.2019).

Elizabeth L'Estrange, Holy Motherhood: Gender, Dynasty, and Visual Culture in the Later Middle Ages, Manchester 2008. 
Mary Lewis, Work and the Adolescent in Medieval England ad. 900-1550: The Osteological Evidence, in: Medieval Archaeology 60,1 (2016), 138-171.

Philip Lindley, Tomb Destruction and Scholarship: Medieval Monasteries in Early Modern England, Donnington 2007.

Martin Lowes, Lately Found at Lewes. Report on the Antiquities, in: Journal of the British Archaeological Association 1 (1846), 353-357.

Lewis C. Loyd, The Origins of the Family of Warenne, in: Yorkshire Archaeological Journal 31 (1934), 97-113.

Sue Margeson, Worked Bone, in: John G. Coad/Anthony D. F. Streeten, Excavations at Castle Acre Castle, Norfolk, 1972-77, in: Archaeological Journal 139 (1982), 138-301, 241-253.

Therese MARTIN (ed.), Reassessing the Roles of Women as "Makers" of Medieval Art and Architecture, Leiden 2012.

Lucien Musset, Les actes de Guillaume le Conquérant et de la reine Mathilde pour les abbayes caennaises, in: Mémoires de la Société des Antiquaires de Normandie 37 (1967), $59-62$.

Kathleen Nolan, Queens in Stone and Silver: The Creation of a Visual Imagery of Queenship in Capetian France, New York 2009.

Kim M. Phillips, A Cultural History of Women in the Middle Ages (The Cultural Histories Series), Sydney 2016.

Rebecca Rushforth, The Crowland Psalter and Gundrada de Warenne, in: The Bodleian Library Record 21 (2008), 156-68.

Birgit SAWYER, Women as Bridge-Builders: The Role of Women in Viking-Age Scandinavia, in: Ian Wood/Niels Lund (eds.), People and Places in Northern Europe 500-1600, Essays in Honour of Peter Hayes Sawyer, Woodbridge 1991.

Ian SHORT, Patrons and Polyglots: French Literature in Twelfth-Century England, in: Anglo-Norman Studies 14 (1991), 229-249.

Eleanor R. Standley, Spinning Yarns: The Archaeological Evidence for Hand Spinning and its Social Implications, c. ad. 1200-1500, in: Medieval Archaeology 60,2 (2016) 266299.

Michael W. Thompson, Keep or Country House? Thin-walled Norman "proto-keeps", in: Fortress 12 (1992), 13-22.

Michael W. Thомpson, Another "Proto-Keep" at Walmer, Kent, in: Medieval Archaeology 39, (1994), 174-176.

Ruth Tringham, A Plea for a Richer, Fuller and More Complex Future Archaeology, in: Norwegian Archaeological Review 51 (2018), 57-63.

Ruth Tringham, Giving Voices (Without Words) to Prehistoric People: Glimpses into an Archaeologist's Imagination, in: European Journal of Archaeology 22,3 (2019), 338-353.

Elizabeth M. Tyler, Crossing Conquests: Polyglot Royal Women and Literary Culture in Eleventh-Century England, in: Elizabeth M. Tyler (ed.), Conceptualizing Multilingualism in Medieval England, c800-c1250 (Studies in the Early Middle Ages 27), Turnhout 2011, 171-196.

Elisabeth van Houts, Memory and Gender in Medieval Europe 900-1200 (Medieval Culture and Society), Buffalo 1999.

Elisabeth van Houts, Hereward and Flanders, in: Anglo-Saxon England 28 (1999), 201223. 
Elisabeth van Houts, Epitaph of Gundrada of Warenne, in: Andreas BiHRER/Elizabeth Stein (eds.), Nova de Veteribus, Mittel-und neulateinische Studien für Paul Gerhard Schmidt, Munchen, Leipzig 2004, 366-378.

Elisabeth van Houts, The Warenne View of the Past 1066-1203, in: Anglo-Norman Studies XXIV, Proceedings of the Battle Conference 200326 (2004), 103-121.

Jennifer WARD, English Noblewomen in the Later Middle Ages (The Medieval World), New York 1992.

Diane WATT, Women, Writing and Religion in England and Beyond, 650-1100 (Studies in Early Medieval History), London 2019.

Margaret Wood, The English Medieval House, London 1965.

George Zarnecki/Janet Holt/Tristram Holland, English Romanesque Art 1066-1200. Catalogue of an Exhibition Held at Hayward Gallery, London, 5 April-8 July 1984. Arts Council of Great Britain 1984. 